\title{
Etika Menangani Komplain Pasien/Keluarganya pada Konteks Layanan Gawat Darurat dan Elektif
}

\author{
Pukovisa Prawiroharjo ${ }^{\mathrm{I}, 2}$, Ghina Faradisa Hatta, Anna Rozaliyanii, ${ }^{\mathrm{r}, 3}$, Fadlika Harinda, Prijo Sidipratomo ${ }^{\mathrm{I}, 4}$ \\ ${ }^{\mathrm{I}}$ Majelis Kehormatan Etik Kedokteran Pengurus Besar Ikatan Dokter Indonesia \\ ${ }^{2}$ Departemen Neurologi Fakultas Kedokteran Universitas Indonesia/Rumah Sakit Cipto Mangunkusumo \\ ${ }^{3}$ Departemen Parasitologi Fakultas Kedokteran Universitas Indonesia \\ 4Fakultas Kedokteran Universitas Pembangunan Nasional Veteran Jakarta
}

\author{
Kata Kunci \\ Etika, komplain, penanganan komplain, \\ gawat darurat, elektif \\ Korespondensi \\ anna.rozaliyani@ui.ac.id \\ Publikasi \\ (C) $2020 \mathrm{JEKI} /$ ilmiah.id \\ DOI \\ Io.26880/jeki.v4ii.40 \\ Tanggal masuk: I4 November 2019 \\ Tanggal ditelaah: II Januari 2020 \\ Tanggal diterima: 1o Februari 2020 \\ Tanggal publikasi: 24 Februari 2020
}

Abstrak Ketika perlakuan dokter dalam konteks layanan kesehatan tidak memenuhi ekspektasi pasien/keluarganya, maka komplain akan muncul. Tidak jarang terdapat kesenjangan antara apa yang diharapkan dengan pertimbangan klinis yang melatarbelakangi perlakuan dokter terhadap pasien. Dalam konteks emergensi, pemusatan perhatian tenaga kesehatan untuk menangani komplain dapat membawa risiko tambahan terhadap pasien yang membutuhkan penanganan gawat darurat. Untuk itu, manajemen rumah sakit perlu untuk membentuk tim khusus penanganan komplain. Dalam menangani komplain, dokter disarankan untuk mendengarkan keluhan terlebih dahulu sebelum memberikan respons, mengingat komplain adalah sarana evaluasi pelayanan yang baik.

\begin{abstract}
When the conduct of doctors in providing healthcare services does not meet the expectations of the patient/family, complaints are apt to surface. It is not uncommon for gaps to exist between what is expected and the clinical considerations underlying the doctor's treatment towards the patient. In emergency settings, focusing on handling complaints can bring additional risks to patients who need urgent care. For this reason, hospital managements need to form a special team to handle complaints. As for elective contexts such as polyclinics and hospitalizations, doctors have more room to handle complaints that are of a health service nature. In handling complaints, doctors are advised to listen to complaints first before responding, especially because complaints can be valuable in evaluating healthcare services.
\end{abstract}

Beberapa dekade terakhir, jumlah tuntutan pasien/keluarganya terhadap dokter/tenaga kesehatan semakin meningkat. Tidak jarang ditemukan adanya berbagai komplain dari masyarakat terkait layanan kesehatan. Adanya komplain dapat menjadi refleksi pelayanan dengan umpan balik secara aktif. Akan tetapi, ketika dihadapkan pada konteks situasi layanan medis yang kurang tepat, penanganan komplain dapat menyebabkan dilema etis dan diperlukan tinjauan etika terkait penanganan komplain tersebut.

\section{Prinsip Dasar Penanganan Komplain Pasien}

Pasien/keluarganya berhak untuk mengajukan komplain secara langsung kepada seorang dokter apabila terdapat hal-hal berikut:
(1) Kesalahan profesional (professional misconduct) dan (2) Kinerja profesional yang buruk. Yang dimaksud dengan kesalahan profesional adalah perilaku dokter yang dianggap memalukan atau tidak terhormat, yaitu perilaku yang tidak memenuhi standar perilaku dokter sesuai dengan kode etik profesi yang berlaku. Kinerja profesional yang buruk diartikan sebagai kegagalan dokter untuk memenuhi standar kompetensi, baik dalam pengetahuan dan keterampilan maupun penerapan pengetahuan dan keterampilan yang dimiliki. ${ }^{1}$

Beberapa hal yang tidak jarang menjadi dasar komplain yang dilayangkan oleh pasien/ keluarganya, antara lain: (1) Kesalahan yang tidak bertanggung jawab atau kesalahan berulang dalam pemberian resep, misalnya 
resep obat dengan cara yang berlebihan atau berbahaya, (2) Kegagalan dalam perawatan atau pemeriksaan pasien dengan benar, (3) Hubungan dan perilaku yang tidak pantas, (4) Kesalahan diagnosis, (5) Pemeriksaan yang tidak rasional, (6) Penipuan atau ketidakjujuran, (7) Pelanggaran serius teradap kerahasiaan medis pasien, dan (8) Inkompetensi klinis. ${ }^{1}$

\section{Komplain dalam Konteks Layanan Gawat}

Darurat Kode Etik Kedokteran Indonesia (KODEKI) tahun 2012 Pasal 17 menyatakan bahwa dokter wajib melakukan pertolongan gawat darurat sebagai suatu wujud tugas perikemanusiaan, kecuali bila ia yakin ada orang lain bersedia dan mampu memberikannya. ${ }^{2}$ Pada suasana dinas di layanan emergensi misalnya di unit gawat darurat, tidak jarang ketersediaan tenaga kesehatan, termasuk dokter, tidak sebanding dengan jumlah pasien yang memerlukan penanganan gawat darurat. Terlebih lagi pasien emergensi memerlukan upaya yang lebih besar dan evaluasi klinis yang lebih sering (bahkan dapat diperlukan evaluasi tiap menit) yang sangat menyita perhatian dokter dan tim tenaga kesehatan.

Persepsi tingkat kegawatdaruratan antara pasien/keluarganya yang tidak mengetahui ilmu medis dengan dokter jaga pastilah sangat berbeda. Perbedaan ini dapat memunculkan persepsi negatif dari pasien/keluarga, misalnya pada kasus medis dengan skala paling tidak prioritas dari ragam kasus gawat darurat yang ditangani pada saat yang sama. Munculnya persepsi ini juga dapat didukung oleh adanya anggapan pasien/keluarganya bahwa kondisi medis pasien saat itu adalah kondisi terberat yang pernah mereka alami. Pasien yang baru kali ini mengalami penyakit berat merasa berhak mendapat layanan super cepat dan tanggap, terlebih jika pasien/keluarganya memiliki kemampuan finansial lebih dan terbiasa mendapat layanan "karpet merah" dalam kesehariannya di perbankan, perusahaan, dan sebagainya.

Padahal, dalam setting layanan emergensi terdapat sejumlah pasien dalam kondisi gawat darurat dan prioritas penanganannya dilakukan menurut pertimbangan kondisi medis pasien sehingga bisa saja pasien tersebut justru tergolong paling tidak prioritas untuk ditangani kegawatdaruratannya di saat tersebut. Kurangnya pemahaman pasien dapat membuat dokter dan tim dipersepsi kurang memberi perhatian pada pasien tersebut karena perhatiannya tersita lebih besar pada pasien lain yang lebih gawat darurat. Pasien/keluarganya seringkali dengan mudahnya menilai dokter dan tim sebagai tenaga kesehatan yang tidak tanggap, kurang peduli, dan mengacuhkan pasien yang sedang sakit.

Terlebih jika pasien/keluarganya melihat dokter yang memberikan intensitas perhatian yang berbeda antar pasien sebagai persepsi dokter "pilih kasih" dan "melakukan diskriminasi”. Padahal, dokter bekerja sesuai standar profesionalismenya dengan memberikan perhatian yang lebih pada kasus yang memang lebih prioritas tingkat kegawatdaruratannya. Sikap yang seperti ini justru adalah sikap profesional yang etis dan adil. Kesenjangan persepsi seperti itulah yang dapat menjadi awal mula munculnya komplain.

Terdapat pula perbedaan persepsi pasien/ keluarganya saat melihat dokter "tampak asyik bermain gawai" saat jaga di UGD, sementara dokter dianggap belum merawat secara memadai. Padahal gawai dipakai dokter jaga tersebut mungkin untuk berkoordinasi dengan dokter spesialis dan manajemen rumah sakit untuk menyelesaikan permasalahan pasien gawat darurat yang sedang ditangani.

Dinas kegawatdaruratan yang sedemikian sibuk dengan waktu yang sedemikian sempit, akan semakin terhimpit dengan adanya komplain dari salah seorang pasien/keluarganya yang muncul karena perbedaan persepsi tersebut. Komplain yang disampaikan secara keras apalagi sampai mengancam secara lebih jauh, akan menarik atensi tenaga kesehatan yang bertugas kepada komplain tersebut.

Yang kemudian menjadi masalah adalah ketika atensi dokter dan tim yang bertugas teralihkan untuk menangani komplain, maka di saat yang sama menjadi kurang perhatian terhadap kasus-kasus lain yang lebih gawat dan lebih darurat. Meskipun tindakan penanganan komplain yang muncul pada saat itu adalah 
tindakan yang etis dan tergolong baik, namun harus disadari bahwa tindakan itu dapat secara nyata berpotensi merugikan pasien lain terutama pasien yang lebih bersifat gawat dan darurat. Padahal, dalam KODEKI tahun 2012 Pasal 11 dikatakan bahwa setiap dokter wajib senantiasa mengingat kewajibannya melindungi hidup makhluk insani. Oleh karena itu, tindakan ini bisa jadi justru masuk ke dalam perangkap tindakan yang kurang etis pada pasien lain yang lebih membutuhkan atensi dan pertolongan kegawatdaruratan. ${ }^{2}$

Kebanyakan tenaga kesehatan pada konteks layanan gawat darurat akhirnya menangani komplain menggunakan strategi minta maaf dan mengaku salah. Hal itu dilakukan karena berdasarkan pengalaman strategi seperti inilah yang paling cepat meredakan komplain. Strategi ini terpaksa dipilih agar pengalihan atensi tidak berlarut, dan tenaga kesehatan dapat segera melakukan tanggung jawab moralnya kepada pasien lain yang bersifat lebih gawat dan darurat.

Celakanya, strategi permintaan maaf dapat dianggap sebagai kebenaran faktual oleh pasien/ keluarganya sehingga merujuk pada beberapa kasus malah berbuah penuntutan lebih lanjut karena dianggap dokter dan tim mengakui mereka telah berbuat lalai dan tidak adil terhadap pasien/keluarganya. Hal ini dapat pula diperparah dengan pembahasan tuntutan medis lebih lanjut yang tidak mempertimbangkan konteks keseluruhan suasana gawat darurat yang sedang dialami saat itu oleh dokter dan timnya baik di level komite medik RS, komite etika dan hukum RS, Majelis Kehormatan Etik Kedokteran (MKEK), maupun Majelis Kehormatan Disiplin Kedokteran Indonesia (MKDKI). Masalah ini membuat dokter dan tim yang berdinas di setting gawat darurat menjadi khawatir atas kemungkinan untuk dituntut dan merasa tidak dilindungi secara memadai, baik oleh RS, organisasi profesinya, Konsil Kedokteran Indonesia (KKI), maupun negara (jika opsi yang diambil pasien/keluarganya adalah tuntutan hukum) pada kasus di mana mereka menjadi sasaran tuntutan medis tersebut.

\section{Saran Penanganan Komplain dalam Konteks Layanan Gawat Darurat}

Kami mengajukan saran bahwa pada konteks layanan gawat darurat, di mana waktu sangat berharga untuk menolong pasien gawat dan darurat, penanganan komplain dapat dilakukan oleh pihak RS melalui petugas khusus atau rangkap fungsi yang diberi kewenangan oleh Direktur Utama, dan sedapat mungkin merupakan non-tenaga kesehatan. Hal ini dimaksudkan agar seluruh tenaga kesehatan yang berdinas dapat fokus menjalankan kewajiban moralnya tanpa ada pasien gawat darurat yang menjadi tumbal akibat penyitaan perhatian untuk penanganan komplain. Petugas yang menangani komplain tersebut setidaknya dapat membantu meredakan situasi serta menyaring informasi untuk kemudian diteruskan kepada dokter/tim yang relevan.

\section{Komplain dalam Konteks Layanan Elektif}

Pada konteks rawat jalan dan rawat inap di mana kondisi medis pasien secara umum mayoritas adalah elektif, tidak sedikit pula komplain dilayangkan oleh pasien/keluarganya. Dalam studi literatur di RSUD Dr. Soetomo didapatkan keluhan yang ditemukan sering berkaitan dengan antrian poli/instalasi rawat jalan. ${ }^{3}$

Banyaknya pasien yang berobat di instalasi rawat jalan harus berbenturan dengan waktu yang terbatas. Hal ini kemudian menjadikan dokter dan tenaga kesehatan lainnya tampak tergesa-gesa atau terkesan kurang meluangkan waktu untuk pemeriksaan padahal pasien dan keluarganya telah lama mengantri sejak dini hari. Hal tersebut tidak jarang menimbulkan persepsi di mata pasien/keluarganya bahwa pemeriksaan yang dilakukan terkesan 'asalasalan' dan yang penting cepat selesai. Padahal, pelayanan yang diberikan telah disesuaikan agar tetap efektif dan efisien.

KODEKI Pasal 10 menyatakan bahwa dokter wajib menghormati hak pasien dan wajib menjaga kepercayaan pasien. ${ }^{1}$ Adanya perbedaan persepsi tersebut berpotensi untuk menurunkan kepercayaan pasien terhadap dokter dan pelayanan di RS. 


\section{Saran Penanganan Komplain dalam Konteks Elektif}

Jika isi komplain pasien tersebut terkait upaya diagnosis dan tata laksana pasien, dokter penanggung jawab layanan di instalasi rawat jalan serta timnya dapat menjadi pihak pertama untuk menangani komplain tersebut secara langsung dengan baik melalui pendekatan pemahaman pelayanan yang efektif dan efisien kepada pasien/keluarganya. Dokter sebaiknya tidak tergesa-gesa dan/atau langsung membantah untuk membela diri atau merasionalisasikan komplain, padahal bisa jadi komplain tersebut benar dan bersifat membangun. Dalam menghadapi komplain, dokter perlu menunjukkan empati dan berterima kasih atas masukan yang diberikan. Berangkat dari komplain tersebut dokter bisa meningkatkan kualitas pelayanan medis dan menunjukkan perbaikan yang dilakukan atas dasar masukan dari komplain yang diberikan.

Namun, jika isi komplain pasien tersebut lebih terkait pada kebijakan RS, misalnya antrian yang panjang, pencarian rekam medis yang lama, dan sebagainya sebaiknya diarahkan pada Direktur RS. Dokter dan tim yang bekerja dapat membantu mengarahkan komplain tersebut dengan maksud baik agar RS dapat mengambil kebijakan untuk membenahi masalah tersebut.

Di sisi lainnya, jajaran direksi RS dan di staff di bawahnya selayaknya bersedia menerima komplain terkait sistem layanan dengan lapang hati. Direksi RS harus mengedepankan sikap tidak lepas tangan jika komplain yang ada terkait dengan manajemen RS. Komplain yang ada harus dianggap sebagai umpan balik positif demi perbaikan RS. RS perlu untuk membuat sistem penanganan komplain dan mengedukasi pasien/keluarga terkait penyampaian komplain terhadap manajemen RS. Dokter dan tenaga kesehatan yang bekerja dapat memfasilitasi dan mengarahkan pasien/keluarga ke dalam sistem penanganan komplain yang telah dibentuk RS tersebut.

\section{KESIMPULAN}

Dalam bekerja, kita tidak bisa selalu sempurna. Kritik dan saran dapat menjadi sarana refleksi yang baik. Apabila seorang dokter mendapatkan komplain terkait pelayanan yang diberikannya, sebaiknya dokter mendengarkan terlebih dahulu komplain tersebut. Direksi RS juga memiliki peran penting dalam manajamen komplain. Direktur RS perlu membentuk tim penilaian independen yang bertugas untuk menangani komplain yang sifatnya bersinggungan dengan ranah manajemen RS. Bila ditemukan komplain terhadap manajemen RS, dokter dapat membantu dengan mengarahkan pasien/keluarganya untuk menghubungi tim tersebut dan menyuarakan komplain yang dimilikinya.

\section{KONFLIK KEPENTINGAN}

Penulis tidak memiliki konflik kepentingan dalam penulisan artikel ini.

\section{REFERENSI}

1. Medical Council. Grounds for complaints[internet]. 2020[Disitasi pada 2020 Jan]. Dapat diunduh di: https://www. medicalcouncil.ie/Public-Information/ Making-a-Complaint-/Grounds-forComplaints/Grounds-for-Complaints.html

2. Kode etik kedokteran Indonesia tahun 2012. Jakarta: 2012.

3. Muhadi M. Studi penanganan komplain pasien di instalasi rawat jalan (irj) rsud dr. soetomo. Jurnal Manajemen Kesehatan Yayasan RS Dr Soetomo. 2016;2(1):8. 